\title{
ÖSSZEHASONLÍTÓ TANULMÁNY POLIETILÉN HULLADÉKANYAGGAL, ILLETVE CEMENTTEL MEGVALÓSÍTOTT TALAJSTABILIZÁCIÓRÓL
}

\section{COMPARATIVE STUDY ON SOIL STABILIZATION WITH POLYETHYLENE WASTE MATERIALS AND CEMENT}

\author{
Ilieş Nicoleta ${ }^{1}$, Cîrcu Alexandru-Petru ${ }^{2}$, Nagy Andor-Csongor ${ }^{3}$, Ciubotaru Vlad- \\ Costel $^{4}$, Kisfaludi-Bak Zsombor ${ }^{5}$

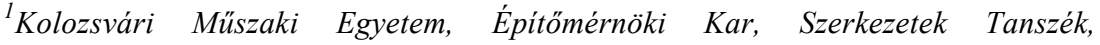 \\ nicoleta.ilies@dst.utcluj.ro \\ ${ }^{2}$ Kolozsvári Müszaki Egyetem, Épitömérnöki Kar, Tartószerkezet-mechanikai Tan- \\ szék, alexandru.circu@mecon.utcluj.ro \\ ${ }^{3}$ Kolozsvári Müszaki Egyetem, Épitőmérnöki Kar, Szerkezetek Tanszék, \\ andor.nagy@yahoo.com \\ ${ }^{4}$ Kolozsvári Müszaki Egyetem, Épitőmérnöki Kar, Szerkezetek Tanszék, \\ ciubotaru.vladcostel@yahoo.com \\ ${ }^{5}$ Kolozsvári Müszaki Egyetem, Épitömérnöki Kar, Tartószerkezet-mechanikai Tan- \\ szék, zsombor.kisfaludi@mecon.utcluj.ro
}

\begin{abstract}
In some cases, the production of solid waste is experiencing an uncontrolled and continuous increase, especially wastes from plastic products. Given that the process of transforming plastic waste into raw material involves high energy consumption, plastic can be used in geotechnics. This paper is based on comparing two solutions to improve the soil. The first solution is to improve the soil with plastic waste and the second solution is to improve the soil with cement. An instability phenomenon in slopes occurs in periods with heavy rainfall. For this reason the samples are immersed in water during the direct shear test. Ongoing tests, performed as a part of the research program have shown the effect of the polyethylene waste material and cement on soil cohesion and internal friction angle.
\end{abstract}

Keywords: waste material; soil stabilization; direct shear test; polyethylene

\section{Összefoglalás}

Esetenként a szilárd hulladék termelése folyamatos és megállíthatatlan folyamatnak tünik, különösen a mủanyagszármazékok kapcsán. A mủanyag hulladékok nyersanyaggá alakítási folyamatában, habár nagy mennyiségü energiát használ fel, a keletkezett termék felhasználható a geotechnika területén. Ezen dolgozat két talajjavító megoldás eredményeinek összehasonlításán alapszik. Az első megoldásnál a talaj-polietilén, míg a másodiknál talaj-cement együttest vizsgáltuk. Erős esőzésekkor felléphet a lejtők stabilizációjának problémája, ezért a közvetlen nyírási kísérleteket vízzel telített talajpróbákon végeztük. A kutatás során végzett kísérletek kimutatják a polietilén hulladékanyag és a cement hatását a talaj kohéziójára és belső súrlódási szögére.

Kulcsszavak: talajstabilizáció, közvetlen nyírási kísérlet, hulladékanyag, polietilén 


\section{Bevezető}

A talaj-cement nem más, mint talaj, víz és cement jól tömörített keveréke. Nagymértékben alkalmazzák utak, parkolóövezetek, gátak és töltések talajalapzatának javításánál. Első alkalommal a United States Bureau of Reclamation (USBR) alkalmazta a keveréket a Bonny gát lejtöcsuszamlás elleni védelmében egy kísérleti sávban. Tízévi megfigyelés után a megoldás eredményei jónak bizonyultak [4]. A kelet-coloradói Bonny gyüjtő 33 évi fagyási-olvadási ciklust, illetve számtalan szárazsági vagy nedvességi periódust szenvedett el. Az eredmények elég figyelemre méltóak, annak ellenére, hogy a keverési folyamat helyben, a terepen zajlott. Eróziós üregek jöttek létre a réteg alján, az alacsonyabb cementkoncentrátum és a kisebb mértékü tömörítés miatt [4]. Az oklahomai Optima gátnál a Mérnöki Testület mintákat vett a stabilizáló talaj-cement keverékéből egy év elteltével, és jó eredményeket közöltek a rétegek kapcsolódásáról. Brown és Root jó rétegkapcsolódásról jelentettek egy hütő tónál a dél-texasi atomerőmünél, ahol a száraz cement kötőanyag tulajdonságait használták fel [1]. A Cheney gát viselkedése megtalálható Holtz és Hansen, Gray Davis és Jones cikkeiben [2, 3]. Romániában árvíz elleni védőgátaknál alkalmaztak talajcement keveréket. Az Olt megyei Icoana település Vedea folyóján található ilyen árvízvédelmi munkálat. Itt alkalmazták elöször a technológiát Romániában töltések építésénél, mivel a helyi földbirtokosok idegenkedtek a nagyobb területeket elfoglaló megoldásoktól. Ily módon a töltésépítés által elfoglalt föld területe feleződött, mivel a töltéskeresztmetszet dőlési szöge nagymértékben emelkedhetett.

A müanyag hulladékok felhasználását talajstabilizációk esetén szintén számos kutatási programban vizsgálták világszerte. Egy W.R. Azzram [5] által vezetett elemzés egy olyan alkalmazását mutatja be a polimer stabilizációnak, amellyel új nanokompozit anyagot valósítanak meg, agyagos földdel. A polipropilén stabilizáló hatását a mikrostrukturákra és agyagtulajdonságokra különböző kísérletek során vizsgálták, ahol változó polimermennyiségeket alkalmaztak. A vizsgálatok kimutatták, hogy a keletkezett nanokompozitok töltőanyagként viselkedtek, melyek csökkentették a kezelt agyag képlékenységi és tömöríthetőségi paramétereit. Az épített beékelődés betöltötte a pórusokat, így csökkentette a térfogati zsugorodást, és egy izotróp tömöríthető anyagot hozott létre kisebb kiterjedésü kiszáradási repedésekkel. A nanokompozit méretének növelésével szintén növekedett a húzó-, illetve nyírószilárdság. Botero egyik munkájában [6] ismertetett egy alternatív újrahasznosítási módot, müanyag hulladékokat (müanyagpalackok szálanyagként alkalmazva) felhasználva geotechnikai építkezéseknél. A kutatás során a PET szálakkal erősített iszapos talaj mechanikai viselkedését vizsgálták. Ehhez triaxiális laboratóriumi kísérleteket végeztek (UU) $0,0-1,0 \%$ között szálanyaggal a talaj száraz tömegéhez viszonyítva. Az eredmények azt mutatták, hogy a kezelt talaj nyírószilárdsága a felhasznált szálanyag arányával növekedett. Továbbá az eredmények kimutatták, hogy a kezelt talaj deformációs kapacitása is növekedett, számos geotechnikai probléma esetben pozitív tulajdonságnak számíthat. Összefoglalva: a kezelt talaj érdekes mechanikai tulajdonságokkal bír, így felhasználható olyan szerkezeteknél, ahol magas deformációs kapacitás szükséges, mint például szemétlerakók, szennyvíztisztítók és gátak esetében ahol megakadályozhatja a különféle szivárgásokat.

Más kutatások összekötötték a cementstabilizációt a müanyag származékokkal. Correia egyik cikkében [7] vizsgálta a kötőanyagok és szálelemek mennyiségének hatását a kötőanyaggal stabilizált rövid 
szálelemekkel erősített vagy erősítetlen lágy talaj mechanikai tulajdonságaira. Az eredmények kimutatták, hogy a kötőanyag koncentrációjának emelése növeli a merevséget, a nyomó- és húzószilárdságot, de kisebb hatása van szálelemekkel erősített talajon. Általában kis mennyiségü szálelem hozzáadása a stabilizált lágy talajhoz csökkenti a merevséget, nyomószilárdságot és nyírószilárdságot, és képlékenyebbé változtatja a törékeny viselkedést. A [8] dolgozatban Chen polipropilén szálakkal erősített cement-agyag-keverék szilárdsági vizsgálatát mutatja be. Az újrahasznosított polimer textil szövet tömörített útburkolatoknál volt felhasználva. A szálerősítések hatékonysági vizsgálatának érdekében laboratóriumi kísérleteket végeztek szálakkal erősített cementel vegyített Shanghai agyagon. A kíséreletek során kétféle szálelemet alkalmaztak. Az első egyszálas polipropilén szál, második pedig polimer textilanyagból származó szálköteg volt. A kísérleteket korlátlan nyomószilárdsági kísérleti berendezéssel végezték. Az eredmények kimutatták, hogy a száladalék lényegesen növelheti a cementel kezelt Shanghai agyag szilárdságát és képlékenységét. Mindkét szálelem esetén a szilárdsági csúcsot $0,5 \%$-os menynyiségnél érték el. Habár a polipropilén szálak esetén az eredmények jobbak, a különbségek 5\% alattiak. Ezek alapján a polimer textilanyagból származó szálelem is felhasználható, s ez egy nagy lépést jelenthet a hasonló anyagok újrahasznosításában.

Jelen dolgozat a korábbi, Ilieş által vezetett kutatások [11, 12, 13] folytatása, melyek a mechanikai paraméterek változását vizsgálták talajstabilizációk esetén, edometrikus és közvetlen nyírási berendezésekkel. Az eredmények alapján az agyagos talaj polietilénnel való keverése hasznosnak bizonyult a kompaktállási tulajdonságok tekintetében, mivel csökkentek a talajdeformációk, továbbá a keverék merev- sége is növekedett. Meglepö módon kisebb százalékú polietilén hulladékanyag használata jobb eredményekkel járt, mint magasabb értékek esetén.

Jelen dolgozatban az alábbi jelöléseket alkalmaztuk:

c kohézió,

$\mathrm{c}_{\text {rez }}$ maradó kohézió,

$\varphi \quad$ legnagyobb belső súrlódási szög,

$\varphi_{\mathrm{rez}}$ maradó belső súrlódási szög.

\section{Anyagok és módszerek}

Az elvégzett kísérletek fő célja a nyírási paraméterek változásának vizsgálata cement- vagy polietilén adalék esetén $2,4,6$ és $8 \%$-os mennyiségekben. A kezdeti paraméterek meghatározása érdekében szürövizsgálatokat végeztünk. Az eredmények kimutatták, hogy a talaj iszapos agyag. A minták származási helye egy Kolozsvár melléki telep, 1 méter mélységböl.

1. táblázat. Talajszemcse-méretek

\begin{tabular}{|c|c|c|}
\hline Talajtípus & Átmérö $[\mathrm{mm}]$ & Százalék \\
\hline Agyag & $\mathrm{Cl}: \mathrm{d}<0.002$ & 24.35 \\
\hline Iszap & $\begin{array}{c}\mathrm{FSi}: \\
0.002<\mathrm{d}<0.0063\end{array}$ & 14.87 \\
\hline & $\begin{array}{c}\mathrm{MSi}: \\
0.0063<\mathrm{d}<0.02\end{array}$ & 34.16 \\
\hline & $\begin{array}{c}\mathrm{CSi}: \\
0.02<\mathrm{d}<0.063\end{array}$ & 14.23 \\
\hline Homok & $\mathrm{FSa}: 0.063<\mathrm{d}<0.2$ & 12.39 \\
\hline
\end{tabular}

A minta fizikai tulajdonságai a 2. táblázatban találhatók. A duzzadási-zsugorodási potenciált figyelembe véve a talaj egy aktív agyag.

Az optimális víztartalom meghatározása érdekében végeztünk egy Proctor vizsgálatot. Az eredményezett görbe alapján az optimális víztartalom $19 \%$.

A talajminta kohéziója és belső súrlódási szöge meghatározható a közvetlen nyírási kísérlet segítségével. A kísérletsorozat három mintát igényel, egy adott nyírási felületet, de három különböző függőleges nyo- 
Ilieş Nicoleta, Cîrcu Alexandru-Petru, Nagy Andor-Csongor,

Ciubotaru Vlad-Costel, Kisfaludi-Bak Zsombor

másértéket. Az eredményeket feltüntetve a koordináta-rendszerben három pontot kapunk, amelyeket összekötve, a Coulombegyenesen keresztül meghatározhatjuk a kohéziót és a belső súrlódási szöget. Az első minták az eredeti vízzel telített talajminták. A kísérlet az 1. ábrán figyelhető meg.



1. ábra. Közvetlen nyírási kisérlet vizzel telitett mintával.

2. táblázat. Fizikai tulajdonságok

\begin{tabular}{|c|c|}
\hline Tulajdonság & Átlagérték \\
\hline Víztartalom, $\mathrm{w}$ & $17,48 \%$ \\
\hline Térfogatsúly, $\gamma_{\mathrm{s}}$ & $26,68 \mathrm{kN} / \mathrm{m}^{3}$ \\
\hline $\begin{array}{c}\text { Száraz térfogatsúly, } \\
\gamma_{\mathrm{d}}\end{array}$ & $17,17 \mathrm{kN} / \mathrm{m}^{3}$ \\
\hline $\begin{array}{c}\text { Nedves térfogat- } \\
\text { súly, } \gamma\end{array}$ & $20,17 \mathrm{kN} / \mathrm{m}^{3}$ \\
\hline Porozitás, $\mathrm{n}$ & $35,51 \%$ \\
\hline Hézagtényező, $\mathrm{e}$ & 0,55 \\
\hline Sodrási határ, $\mathrm{wp}$ & $17,38 \%$ \\
\hline Folyási határ, $\mathrm{wl}$ & $42,81 \%$ \\
\hline Plasztikus index, Ip & $25,42 \%$ \\
\hline $\begin{array}{c}\text { Konzisztencia in- } \\
\text { dex, Ic }\end{array}$ & 1,00 \\
\hline
\end{tabular}

A kohézió és a belső súrlódási szög értékei: $\mathrm{c}=74,48 \mathrm{kPa}, \varphi=13,35^{\circ}$, a maradó értékek pedig $\mathrm{c}_{\mathrm{rez}}=21,57 \mathrm{kPa}, \varphi_{\mathrm{rez}}=9,75^{\circ}$.

A második rend kísérlet 2\%-os cementtalaj keveréken zajlott. A minták az elnyírt felülettel a 2. ábrán láthatók.

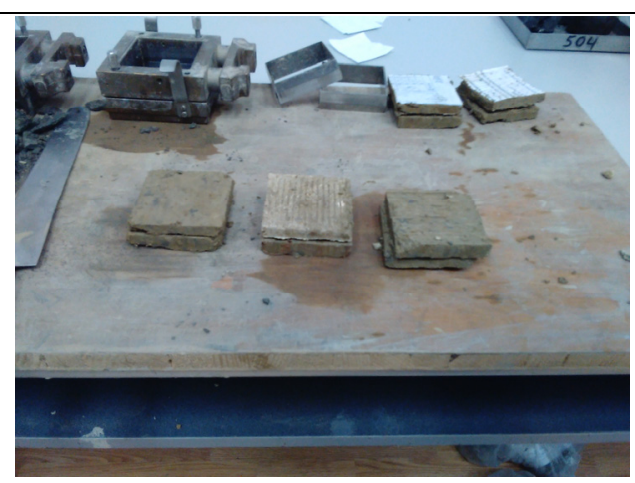

2. ábra. Közvetlen nyírási kisérlet mintái

A kohézió és a belső súrlódási szög értékei: $\mathrm{c}=66,44 \mathrm{kPa}, \varphi=22,29^{\circ}$, a maradó értékek pedig $\mathrm{c}_{\mathrm{rez}}=24,97 \mathrm{kPa}, \varphi_{\mathrm{rez}}=11,83^{\circ}$, a-mint a 3. ábrán is megfigyelhetö. Kis mennyiségü cement hozzáadásával nőtt a belső súrlódási szög, és csökkent a kohézió. A kék vonal jelenti a Coulomb-egyenest az első szakaszban, míg a piros a maradó nyírási értékeket jelzi. Körök jelképezik a 100, 200 , illetve $300 \mathrm{kPa}$-os függöleges nyomásokra a nyírási paramétereket.

A harmadik kísérletnél a cementtartalom 4\%-os. A kohézió és a belső súrlódási szög értékei: $\mathrm{c}=47,77 \mathrm{kPa}, \varphi=35,01^{\circ}$, a maradó értékek pedig $\mathrm{c}_{\mathrm{rez}}=12,63 \mathrm{kPa}$, $\varphi_{\text {rez }}=34,14^{\circ}$, ahogy a 4. ábrán is megfigyelhető. A cementtartalom növelésével a kohézió továbbra is csökken, míg a belső súrlódási szög nő.

A cementtartalom további növelésével már 6\%-os értéken történt a negyedik vizsgálat. A kohézió és a belső súrlódási szög értékei: $\mathrm{c}=80,62 \mathrm{kPa}, \varphi=30,66^{\circ}$, a maradó értékek pedig $\mathrm{c}_{\mathrm{rez}}=12,57 \mathrm{kPa}$, $\varphi_{\text {rez }}=20,48^{\circ}$, ahogy az 5. ábrán is megfigyelhető. A negyedik vizsgálat a kezdeti kohézió és a belső súrlódási szög értékéinél is nagyobbakat eredményez.

Az utolsó, 8\% cementel kevert talaj vizsgálatával ellenőrizhető, hogy a nyírási paraméterek változása követi-e az eddig megfigyelteket. A kohézió és a belső súrlódási szög értékei: $\mathrm{c}=108,76 \mathrm{kPa}$, 
Összehasonlitó tanulmány polietilén hulladékanyaggal, illetve cementtel megvalósitott talajstabilizációról

$\varphi=27,90^{\circ}$, a maradó értékek pedig vizsgálatnál a kohézió továbbra is nőt, míg $\mathrm{c}_{\text {rez }}=9,28 \mathrm{kPa}, \varphi_{\text {rez }}=24,75^{\circ}$, ahogy a a belső súrlódási szög csökkenni kezdett.

6. ábrán is megfigyelhető. Ezen utolsó

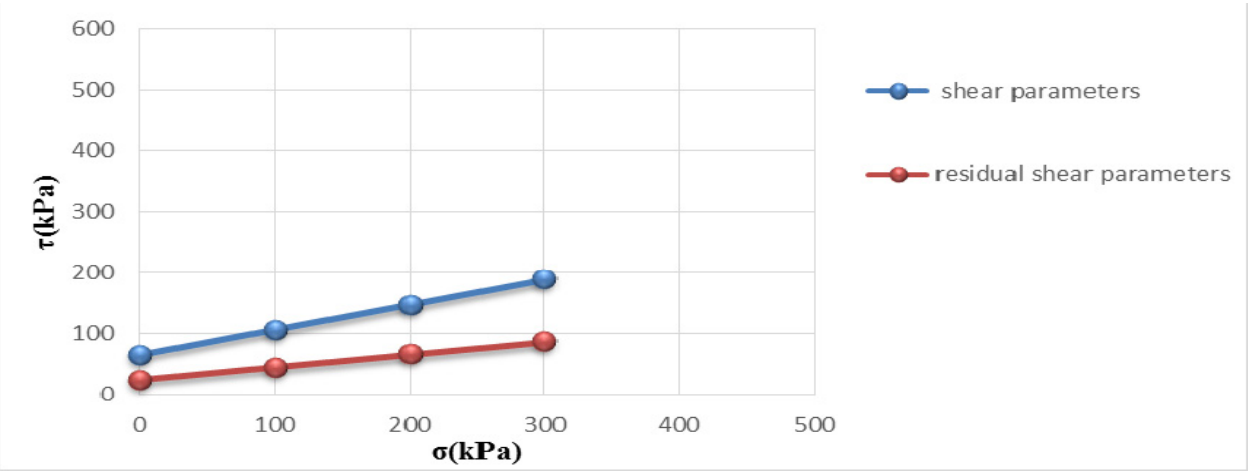

3. ábra. Coulomb-egyenes $2 \%$-os cement-talaj esetén.

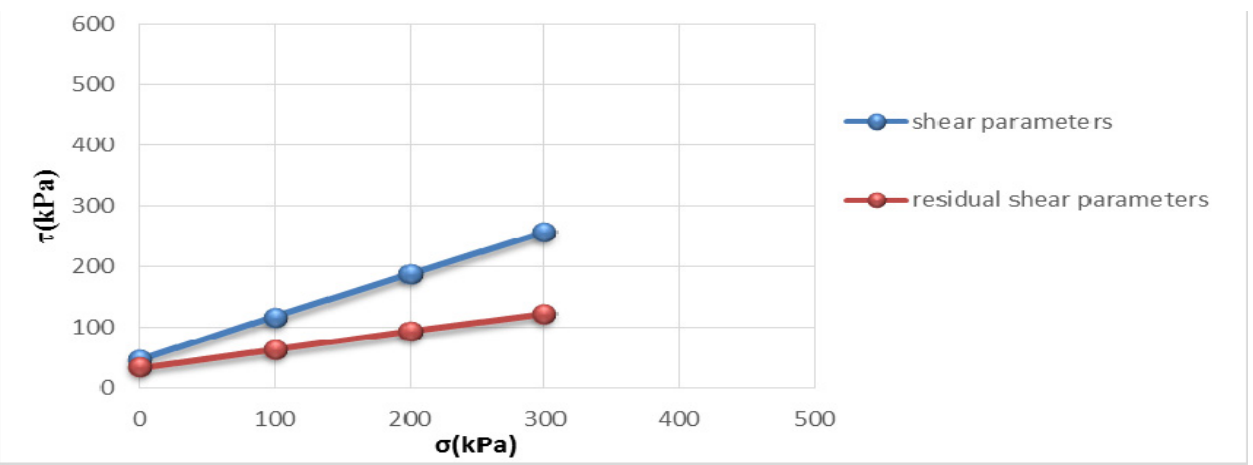

4. ábra. Coulomb-egyenes 4\%-os cement-talaj esetén.

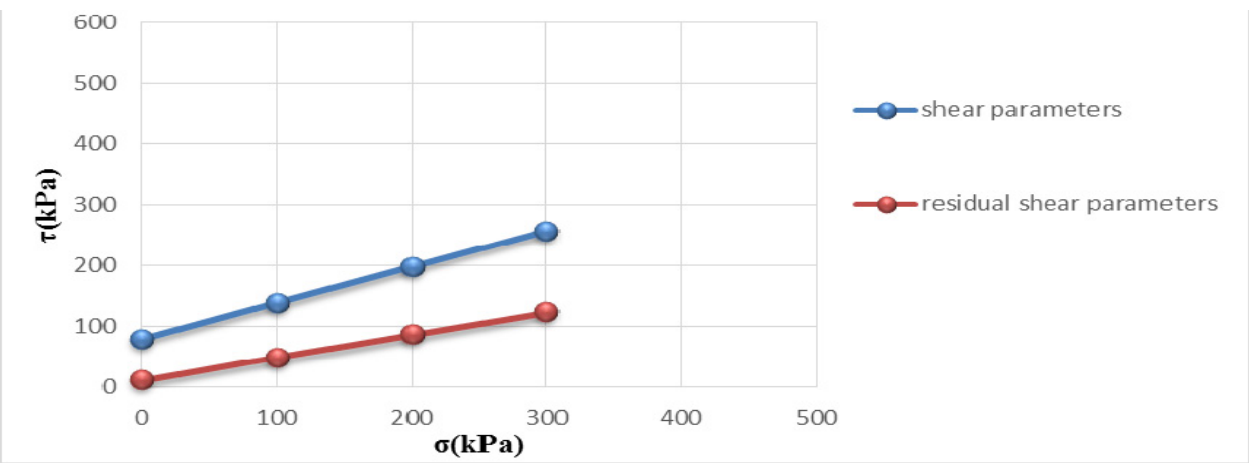

5. ábra. Coulomb-egyenes $6 \%$-os cement-talaj esetén. 
Ilieş Nicoleta, Cîrcu Alexandru-Petru, Nagy Andor-Csongor,

Ciubotaru Vlad-Costel, Kisfaludi-Bak Zsombor

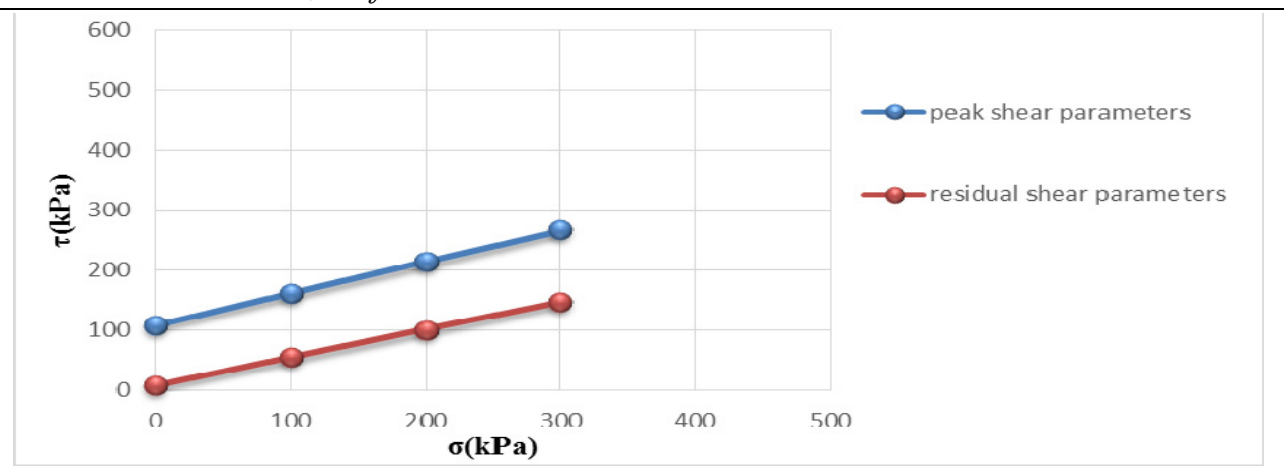

6. ábra. Coulomb-egyenes 8\%-os cement-talaj esetén

A kutatás következő lépésében polietilénszármazékkal kevert talajmintákat vizsgáltunk hasonló 2, 4, 6 és 8\% menynyiségekben adagolva. A talajstabilizációhoz polietilénszemcsék voltak alkalmazva egy helyi újrahasznosítóból. A polietilén-talaj keverék összeállítása optimális víztartalomnál történt (19\%), és a közvetlen nyírási kísérletek a cementtalaj nyírási vizsgálatához hasonló körülmények között mentek végbe.

Az első kísérlet 2\%-os polietiléntartalmú mintákon történt. A kísérlet utáni minták megfigyelhetők a 8. ábrán.

3. táblázat. A polietilén hulladékanyag granulometrikus elemzése

\begin{tabular}{|c|c|c|}
\hline \multicolumn{3}{|c|}{ Eredeti tömeg [g]: 500 } \\
\hline $\begin{array}{c}\text { Rosta mére- } \\
\text { te }\end{array}$ & $\begin{array}{c}\text { Fenntartott } \\
\text { anyag tö- } \\
\text { mege } \\
{[\mathrm{g}]}\end{array}$ & $\begin{array}{c}\text { Tömeg } \\
\text { százalék } \\
{[\%]}\end{array}$ \\
\hline $4 \mathrm{~mm}$ & 215 & 43 \\
\hline $2 \mathrm{~mm}$ & 175 & 35 \\
\hline $1 \mathrm{~mm}$ & 85 & 17 \\
\hline $0,5 \mathrm{~mm}$ & 17,5 & 3,5 \\
\hline $0,25 \mathrm{~mm}$ & 7,5 & 1,5 \\
\hline \multicolumn{2}{|c}{}
\end{tabular}

A kohézió és a belső súrlódási szög értékei: $\mathrm{c}=19,60 \mathrm{kPa}, \varphi=24,47^{\circ}$, a maradó értékek pedig $\mathrm{c}_{\mathrm{rez}}=1,12 \mathrm{kPa}$, $\varphi_{\text {rez }}=14,19^{\circ}$, ahogy a 12 . ábrán is megfigyelhetö.
Tehát polietilén kismértékü adagolása esetén az eredeti értékekhez képest a belső súrlódási szög nőtt.

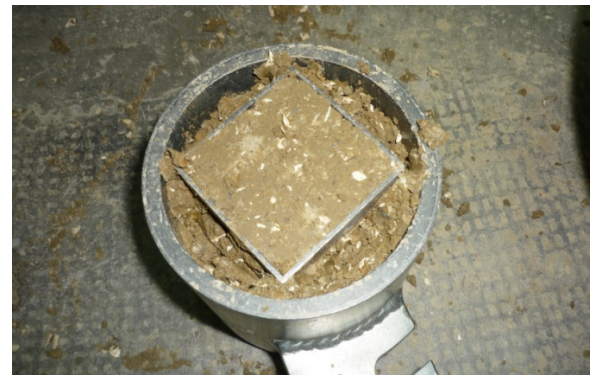

7. ábra. Talaj-müanyag minta

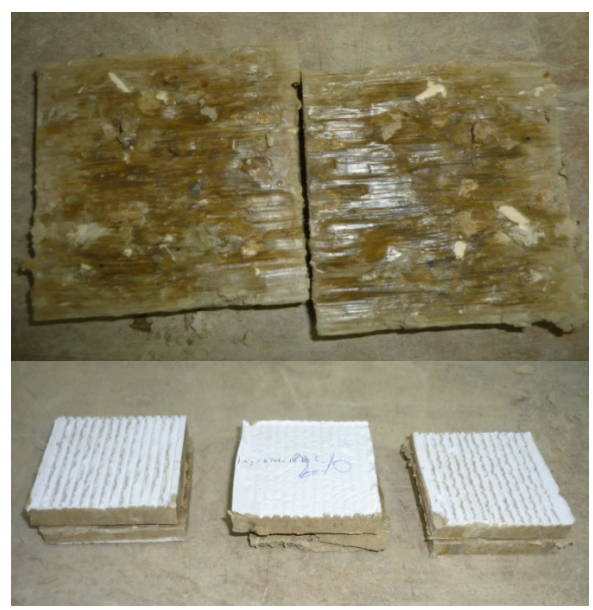

8. ábra. $2 \%$-os polietilén-talaj keverék mintája és annak nyírási felülete 
A második kísérletnél a polietilénarányt megnöveltük 4\%-osra. Ezen mintákat a 10. ábrán mutatjuk. A kohézió és a belső súrlódási szög értékei: $\mathrm{c}=31,41 \mathrm{kPa}, \varphi=21,53^{\circ}$, a maradó értékek pedig $\mathrm{c}_{\mathrm{rez}}=18,13 \mathrm{kPa}, \varphi_{\text {rez }}=9,62^{\circ}$, ahogy a 13. ábrán is megfigyelhető. A polietilénszemek arányának növelésével egyidejüleg nőtt a belső súrlódási szög értéke is, mivel több szem került a nyírási felületre így növelve a nyírási szilárdságot.

A polietilén arányát tovább növeltük 8\%-ra, amint a 10. ábrán is látható.

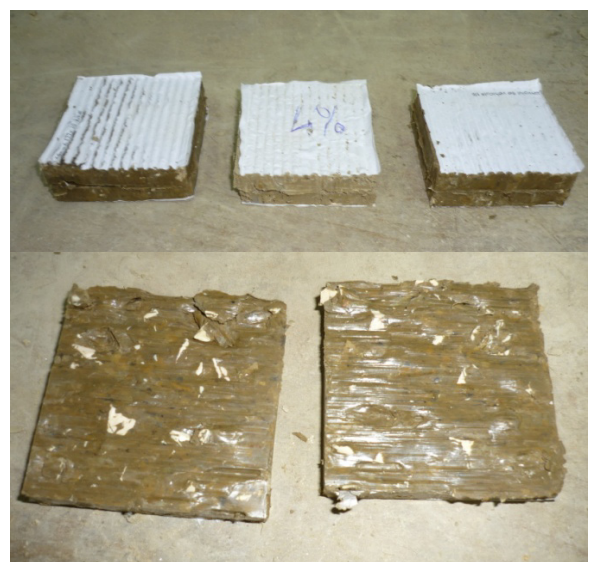

9. ábra. 4\%-os polietilén-talaj keverék mintája és nyirási felülete

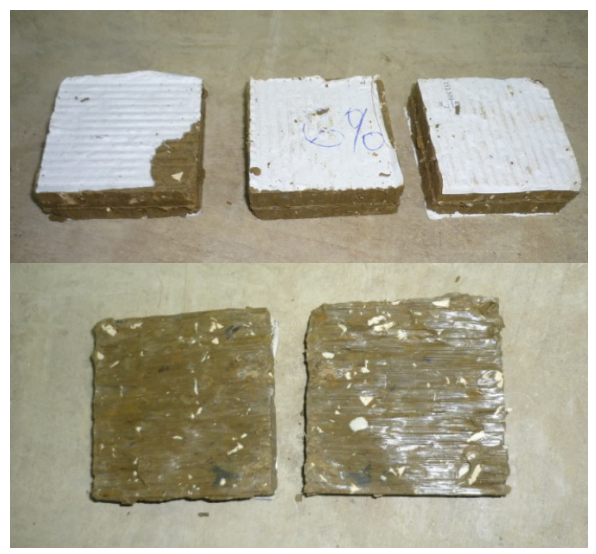

10. ábra. 6\%-os polietilén-talaj keverék mintája és nyírási felülete
A kohézió és a belső súrlódási szög értékei: $\mathrm{c}=5,97 \mathrm{kPa}, \varphi=27,79^{\circ}$, a maradó értékek pedig $c_{\text {rez }}=0,00 \mathrm{kPa}$, $\varphi_{\mathrm{rez}}=19,94^{\circ}$, ahogy a 14. ábrán is megfigyelhetö. A további polietilénarány növelése befolyásolta a belső súrlódási szög mellett a kohéziót is. Habár a kísérletek során a minták vízzel telítettek voltak, a maradó kohéziós érték $0 \mathrm{kPa}$.

Az utolsó kísérlet során a 8\%-os polietilénnel rendelkező mintákat vizsgáltuk a kirajzolódó tendencia ellenőrzésére. A $8 \%$-os polietilén-talaj minták a 11.a. és b. képeken mutatjuk.

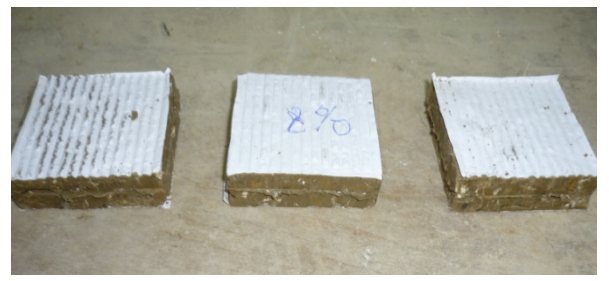

11.a. ábra. $8 \%$-os polietilén-talaj keverék mintája és nyírási felülete

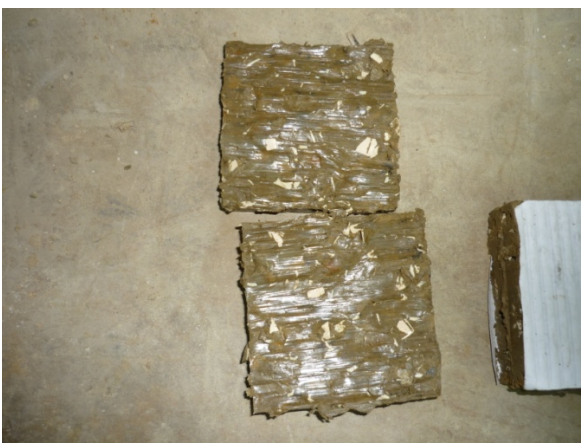

11.b. ábra. $8 \%$-os polietilén-talaj keverék nyírási felülete

A kohézió és a belső súrlódási szög értékei: $\mathrm{c}=10,57 \mathrm{kPa}, \varphi=28,26^{\circ}$, a maradó értékek pedig $c_{\text {rez }}=7,90 \mathrm{kPa}$, $\varphi_{\text {rez }}=17,64^{\circ}$, ahogy a 15 . ábrán is megfigyelhető. Habár kis növekedés észlelhető a kohéziós értékben a 6\%-os mintához 
Ilieş Nicoleta, Cîrcu Alexandru-Petru, Nagy Andor-Csongor,

Ciubotaru Vlad-Costel, Kisfaludi-Bak Zsombor

képest, az eredmények mégis alacso- nyabb értéküek, mint a 4\%-os mintában.

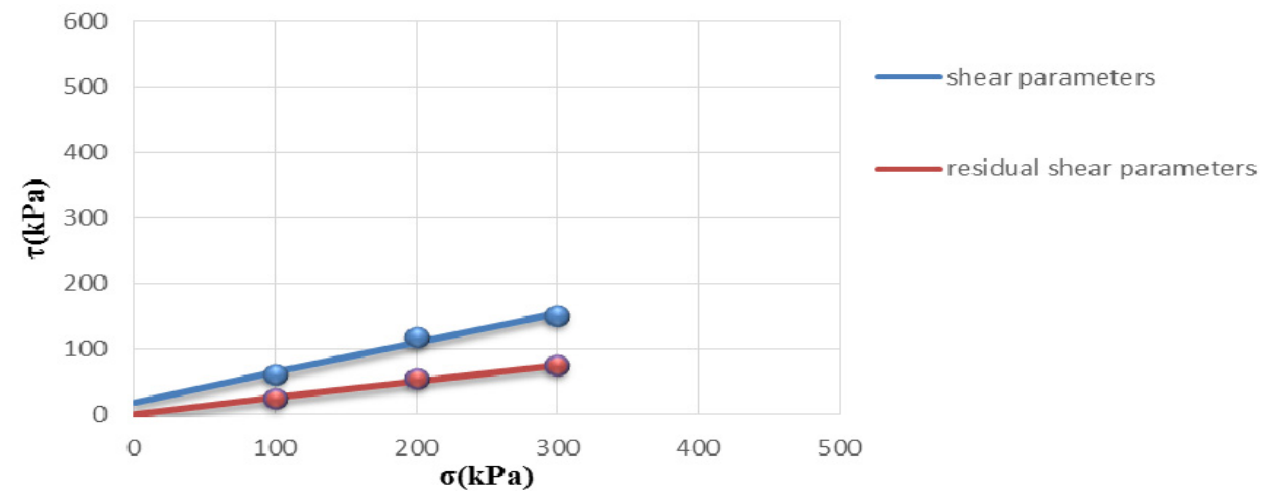

12. ábra. Coulomb-egyenes $2 \%$-os polietilén-talaj esetén.

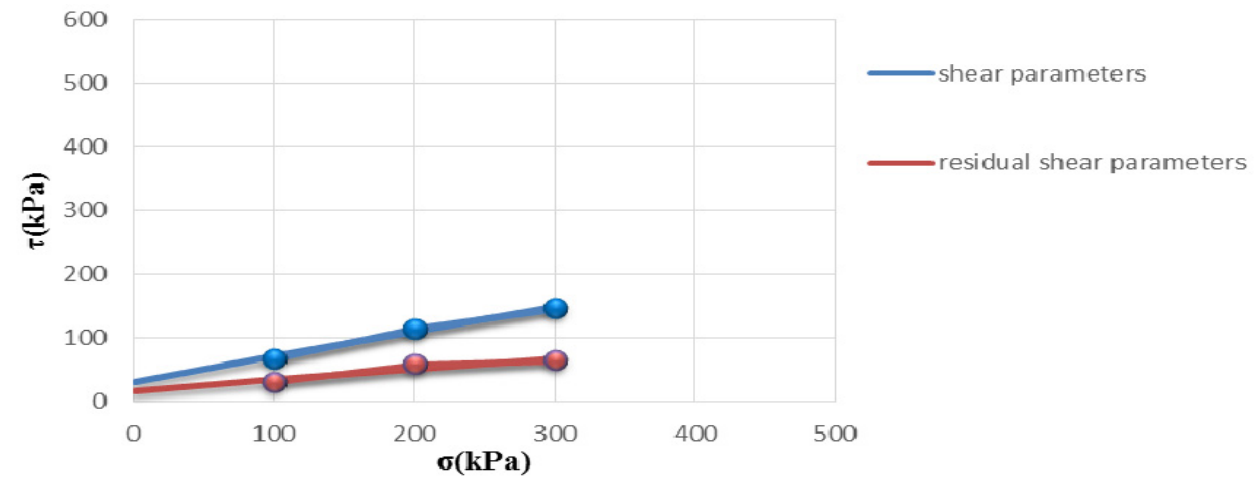

13. ábra. Coulomb-egyenes 4\%-os polietilén-talaj esetén.

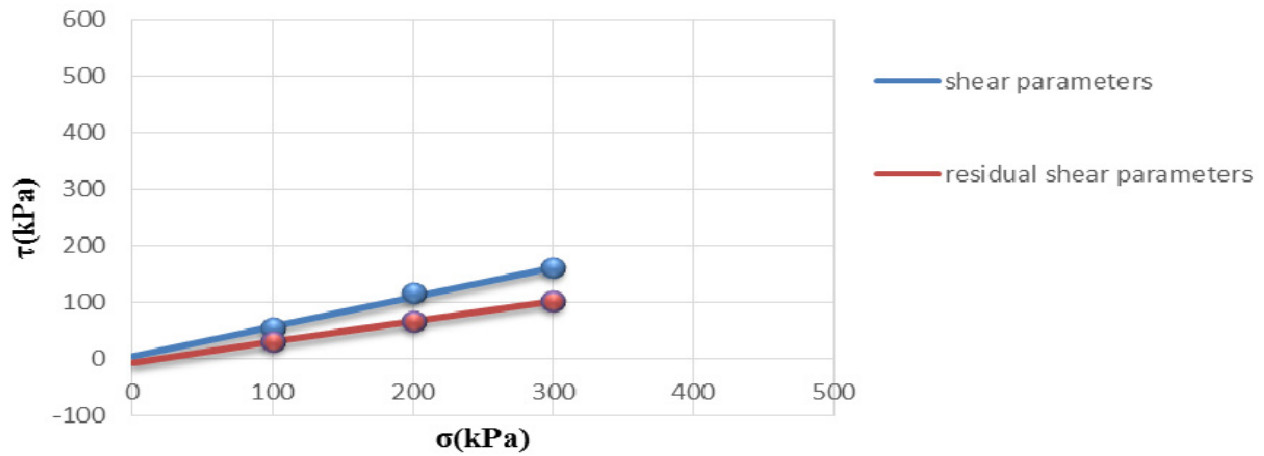

14. ábra. Coulomb-egyenes 6\%-os polietilén-talaj esetén. 

illetve cementtel megvalósitott talajstabilizációról

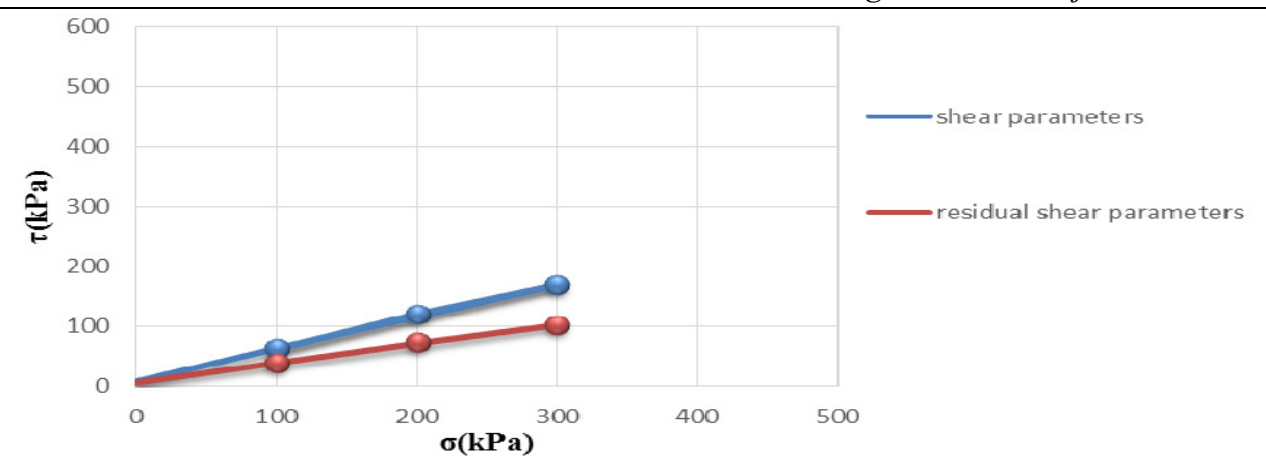

15. ábra. Coulomb-egyenes $8 \%$-os polietilén-talaj esetén.

\section{Eredmények és értékelések}

A közvetlen nyírási kísérlet eredményeit összevetve megfigyelhetjük, hogy cement adagolásával a kohézió növekedett. A cement arányának növelésével a belső súrlódási szög értéke is növekedett már a $\%$-os adagolási értéktől kezdődően. A 2 és 4\%-os értékek növekedése után a $6 \%$-os minták értékei már csökkenő tendenciát mutatnak, amit a 8\%-os minták igazolnak, habár a kezdeti eredményhez képest így is kétszeresek az értékek. A legkiegyensúlyozottabb értékek 6\%-os cementadagolás esetén je- lentkeztek. A közvetlen nyírási kísérlet eredményei a 4. táblázatba vannak foglalva.

A talaj-polietilén keverékek eredményeinek összevetése a 17. ábrán található. Megállapítható, hogy a polietilén adagolása növelte mind a kohézió, mind pedig a belső súrlódási szög értékeit. A 4\%-os keverék kohéziós értéke a legmagasabb, míg a 8\%al rendelkező minták belső súrlódási szöge bizonyult a legnagyobbnak az összes polietilén-talaj minta közül. Ezen eredményeket az 5. táblázat tartalmazza.
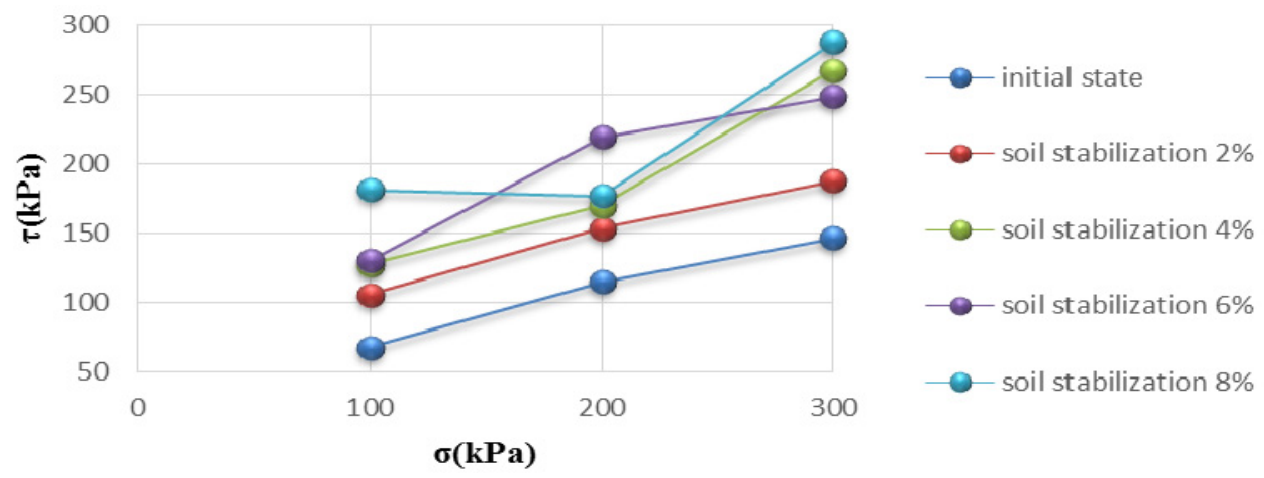

16. ábra. Coulomb-egyenesek a cement-talaj mintáknál. 
Ilieş Nicoleta, Cîrcu Alexandru-Petru, Nagy Andor-Csongor,

Ciubotaru Vlad-Costel, Kisfaludi-Bak Zsombor

4. táblázat. Közvetlen nyirási kisérlet eredményei (talaj-cement minták)

\begin{tabular}{|c|c|c|c|c|c|}
\hline \multirow{2}{*}{$\boldsymbol{\sigma}[\mathbf{k P a}]$} & \multicolumn{5}{|c|}{$\boldsymbol{\tau}$ max [kPa] } \\
\cline { 2 - 6 } & $\begin{array}{c}\text { Természetes } \\
\text { minta }\end{array}$ & $\begin{array}{c}2 \% \text {-os } \\
\text { cement }\end{array}$ & $\begin{array}{c}4 \% \text {-os } \\
\text { cement }\end{array}$ & $\begin{array}{c}6 \% \text {-os } \\
\text { cement }\end{array}$ & $\begin{array}{c}8 \% \text {-os } \\
\text { cement }\end{array}$ \\
\hline 100 & 67,58 & 105,14 & 126,94 & 129,75 & 180,81 \\
\hline 200 & 115,22 & 153 & 169,58 & 219,53 & 176,67 \\
\hline 300 & 146,33 & 187,11 & 267,03 & 248,33 & 287,06 \\
\hline \multicolumn{5}{|c|}{ Maradó értékek } \\
\hline 100 & 41,19 & 40,33 & 68,94 & 51,08 & 62,58 \\
\hline 200 & 53,08 & 78,03 & 83,97 & 84,94 & 87,06 \\
\hline 300 & 78,67 & 82,22 & 128,67 & 125,78 & 154,78 \\
\hline
\end{tabular}

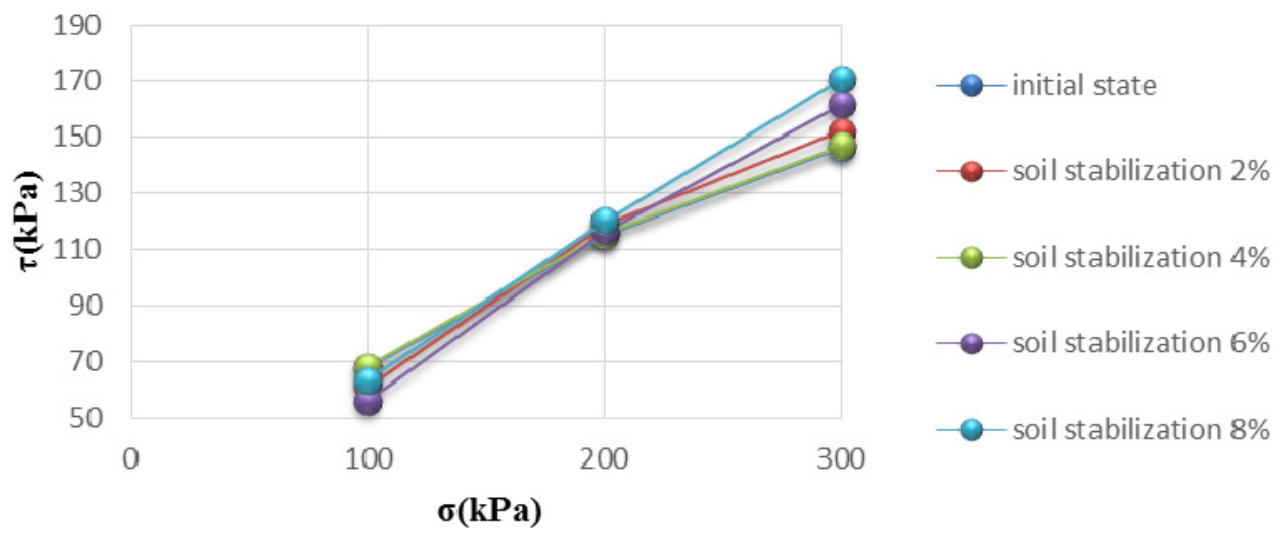

17. ábra. Coulomb-egyenesek a polietilén-talaj mintáknál.

5. táblázat. Közvetlen nyirási kisérlet eredményei (polietilén-talaj minták)

\begin{tabular}{|c|c|c|c|c|c|}
\hline \multirow{2}{*}{$\boldsymbol{\sigma}[\mathbf{k P a}]$} & \multicolumn{5}{|c|}{$\boldsymbol{\tau}$ max [kPa] } \\
\cline { 2 - 6 } & $\begin{array}{c}\text { Természetes } \\
\text { minta }\end{array}$ & $\begin{array}{c}2 \% \text {-os } \\
\text { polietilén }\end{array}$ & $\begin{array}{c}4 \% \text {-os } \\
\text { polietilén }\end{array}$ & $\begin{array}{c}6 \% \text {-os } \\
\text { polietilén }\end{array}$ & $\begin{array}{c}8 \% \text {-os } \\
\text { polietilén }\end{array}$ \\
\hline 100 & 67,58 & 61,17 & 68,14 & 56,08 & 63,25 \\
\hline 200 & 115,22 & 118,47 & 115,78 & 116,58 & 120,58 \\
\hline 300 & 146,33 & 152,17 & 147,06 & 161,50 & 170,78 \\
\hline \multicolumn{5}{|c|}{ Maradó értékek } \\
\hline 100 & 41,19 & 24,56 & 31,69 & 30,36 & 38,72 \\
\hline 200 & 53,08 & 55,42 & 58,83 & 67,94 & 73,47 \\
\hline 300 & 78,67 & 75,14 & 65,61 & 102,92 & 102,33 \\
\hline
\end{tabular}

\section{Következtetések}

A polietilén anyagok használata talajstabilizációhoz környezetbarát meg- oldásnak tekinthető. A polietilénszemek gyártási folyamata kisebb ökológiai lábnyommal bír, mint a cementé vagy más kötőanyagé. Figyelemre méltók a 4\%-os 
polietilén adagolású minták eredményei. Összehasonlítva ezen $4 \%$-os polietilénminták eredményeit a megfelelő cementadagolású minták eredményeivel megállapítható, hogy a kohézió 52\%-kal kisebb, míg a belső súrlódási szög 63\%-kal a polietilén-talaj esetén. Annak ellenére, hogy a cement-talaj minták eredményei magasabb értéküek, előállításuk folyamatának szénkibocsátása nagyobb, így kevésbé környezetbarátok.

\section{Köszönetnyilvánítás}

A müanyag származékokkal történő talajstabilizációs kutatási program a Kolozsvári Müszaki Egyetem által kezdeményezett Internal Research Grant CI 7/1.2/2015: Soil stabilization with plastic waste materials in order to improve physical and mechanical characteristics keretében valósult meg.

Külön köszönet illeti ing. Ilieş Dorut - S.C. Diren Exim S.R.L., a polietilénszármazékok biztosításáért. A cement-talaj típusú stabilizációkkal részletesebben Cîrcu, Ciubotaru és Crăciunescu foglalkoztak mesteri tézisükben [14].

\section{Szakirodalmi hivatkozások}

[1] Dinchak W.B., Soil-cement: it's not just for highways anymore. Concrete Construction January, 1984.

[2] Holtz, Hansen, The use of compacted soilcement in water control structures. 12th Congress of Large Dams, Mexico City, Mexico, 1976.

[3] Davis G., Jones, The Use of soil-cement for slope protection. Eleventh Congress of Large Dams, Madrid 1973.

[4] U.S. Department of the Interior Bureau of Reclamation, Design Standards No. 13Embankment Dams Chapter-17: SoilCement Slope Protection Final: Phase 4, 2013.

[5] Azzam W.R., Behavior of modified clay microstructure using polymer nanocomposites technique. Alexandria Engineering
Journal, Faculty of Geoengineering, 12(2013) 143-150.

[6] Botero E., Ossa A., Sherwell G., OvandoShelley E., Stress-strain behavior of a silty soil reinforced with polyethylene terephthalate (PET). 43 (2015) 363-369.

[7] Correia A.A.S., Oliveira P.J.V., Custodio D.G., Effect of polypropylene fibres on the compressive and tensile strength of a soft soil, artificially stabilized with binders. Geotextiles and Geomembranes, 43(2015), pp. 97-106.

[8] Chen M., Shen S.L., Arulrajah A., Wu H.N., Hou D.W., Xu Y.S., Laboratory evaluation on the effectiveness of polypropylene fibers on the strength of fiberreinforced and cement-stabilized Shanghai soft clay. Geotextiles and Geomembranes, 43 (2015), pp. 515-523.

[9] Vyas S., Phougat N., Sharma P., Ratnam M., Stabilization of Dispersive Soil by Blending Polymers, International Journal of Earth Sciences and Engineering, 04(2011), pp. 52-54.

[10] Cristelo N, Cunha V.M.C.F., Dias M., Gomes A.T., Miranda T., Araújo N., Influence of discrete fibre reinforcement on the uniaxial compression response and seismic wave velocity of a cement-stabilized sandyclay. Geotextiles and Geomembranes, 43(2015), pp. 1-13.

[11] Ilies N.M., Farcaș V.S., Gherman M.C., Chiorean V.F., Popa D., Soils efficient improvement solutions with waste materials and binders. Journal of Environmental Protection and Ecology, Vol. 16, Issue: 4, 2015, pp. 1397-1406 (ISSN: 1311-5065).

[12] Ilies N.M., Farcaș V.S., Mureșan O.C., Gherman M.C., Chiorean V.F., Nagy A.Cs., Îmbunătățirea pământurilor argiloase cu deșeuri din polietilenă. A XIII-a Conferință Naţională de Geotehnică și Fundații - Cluj-Napoca, 07-10 septembrie 2016, pag. 249-258 (ISSN-L 1844 - 850X, Print: ISSN 1844-850X, CD-Rom: ISSN 2285 - 5831).

[13] Ilieş N.M., Farcaş V.S., Mureșan O.C., Gherman M.C., Chiorean V.F., Soil improvement with polyethylene waste materials in order to improve mechanical parameters. 16th International Multidiscipli- 
Ilieş Nicoleta, Cîrcu Alexandru-Petru, Nagy Andor-Csongor,

Ciubotaru Vlad-Costel, Kisfaludi-Bak Zsombor

nary Scientific Geoconference \& Expo SGEM, 2016, Albena, Bulgaria.

[14] Cîrcu Al.P., Ciubotaru V.C., Crăciunescu B., The soil improvement with hydraulic binders experimented to the levees. MSc Thesis in geotechnical engineering, T.U. of Cluj-Napoca, Romania, 2016.
[15] Ilieş N.M., Cîrcu Al.P., Nagy A.Cs., Ciubotaru V.C., Kisfaludi-Bak Zs., Comparative study on soil stabilization with polyethylene waste materials and binders. INTER-ENG 2016. 